\title{
Development of generative structures of polar Caryophyllaceae plants: the Arctic Cerastium alpinum and Silene involucrata, and the Antarctic Colobanthus quitensis
}

\author{
Wioleta KELLMANN-SOPYŁA ${ }^{1}$, Justyna KOC ${ }^{1}$, Ryszard J. GÓRECKI ${ }^{1}$, \\ Marcin DOMACIUK ${ }^{3}$ and Irena GIEŁWANOWSKA ${ }^{1,2 *}$ \\ ${ }^{1}$ Department of Plant Physiology, Genetics and Biotechnology, \\ University of Warmia and Mazury in Olsztyn, Oczapowskiego 1A, 10-719 Olsztyn, Poland \\ 2 Department of Antarctic Biology and Polish Antarctic H. Arctowski Station, \\ Institute of Biochemistry and Biophysics PAS, Pawinskiego 5a, 02-106 Warsaw, Poland \\ ${ }^{3}$ Department of Plant Anatomy and Cytology, Maria Curie-Skłodowska University, \\ Akademicka 19, 20-033 Lublin, Poland \\ *Corresponding author <i.gielwanowska@uwm.edu.pl>
}

\begin{abstract}
The embryology of three polar flowering plants of the family Caryophyllaceae was studied using the methods and techniques of the light, normal and fluorescence microscopes, and the electron microscopes, scanning and transmission. The analyzed species were Colobanthus quitensis of West Antarctic (King George Island, South Shetlands Islands) as well as Cerastium alpinum and Silene involucrata of the Arctic (Spitsbergen, Svalbard). In all evaluated species, flowering responses were adapted to the short Arctic and Australian summer, and adaptations to autogamy and anemogamy were also observed. The microsporangia of the analyzed plants produced small numbers of microspore mother cells that were differentiated into a dozen or dozens of trinucleate pollen grains. The majority of mature pollen grains remained inside microsporangia and germinated in the thecae. The monosporous Polygonum type (the most common type in angiosperms) of embryo sac development was observed in the studied species. The egg apparatus had an egg cell and two synergids with typical polarization. A well-developed filiform apparatus was differentiated in the micropylar end of the synergids. In mature diaspores of the analyzed plants of the family Caryophyllaceae, a large and peripherally located embryo was, in most part, adjacent to perisperm cells filled with reserve substances, whereas the radicle was surrounded by micropylar endosperm composed of a single layer of cells with thick, intensely stained cytoplasm, organelles and reserve substances. The testae of the analyzed plants were characterized by species-specific primary and secondary sculpture, and they contained large amounts of osmophilic material with varied density. Seeds of $C$. quitensis, $C$. alpinum and $S$. involucrata are very small, light and compact shaped.
\end{abstract}


Key words: Antarctic, Arctic, cleistogamous flowers, chasmogamous flowers, seeds,

Colobanthus quitensis, Cerastium alpinum, Silene involucrata, pollen grains.

\section{Introduction}

Clonal growth and vegetative reproduction play a very important role in the propagation of plants inhabiting cold regions of the Earth, including the Arctic, Antarctica and high mountain ranges (Billings and Mooney 1968; Jónsdóttir et al. 1996). In clonally propagated plants, water and minerals can be obtained simultaneously from several sources, and nutrients are effectively managed by circulation inside and between ramets (Jónsdóttir et al. 1996). To date, no evidence has been found to confirm that Colobanthus quitensis (Kunth) Bartl., Cerastium alpinum L. and Silene involucrata (Cham. et Schltdl.) Bocquet, reproduce vegetatively, and the existing populations most probably developed from seeds (Edwards 1972; Parnikoza et al. 2011).

Generative reproduction in polar flowering plants. - Arctic vascular plants develop in a severe climate and produce a small number of mostly non-viable seeds (Billings and Mooney 1968; Bell and Bliss 1980; Phillip et al. 1990). The above is particularly observed in growing seasons with very low temperatures. According to Pirożnikow (1993), generative reproduction is successful in Arctic plants only in seasons with supportive weather, which occurs once every few years or even every decade. Similar observations were made in vascular plants native to Antarctica, Colobanthus quitensis and Deschampsia antarctica Desv. The above species produce numerous flowers and inflorescences every year, but they do not develop mature and fertile seeds regularly in every season (Holtom and Greene 1967; Edwards 1974; Convey 1996).

Bisexual flowers of vascular Antarctic plants are generally cleistogamous, but chasmogamous flowers are also reported. Chasmogamous flowers were produced in seasons with supportive weather conditions and in relatively warm, shielded and quiet microhabitats (Giełwanowska et al. 2005; Giełwanowska et al. 2011; Giełwanowska and Kellmann-Sopyła 2015). In the Antarctic D. antarctica and C. quitensis, cleistogamy probably fulfills the definition of cryocleistogamy because it is induced by low temperature and high humidity, which is also the case in Arctic grasses of the genus Poa (Levkovsky et al. 1981). Most Antarctic phanerogams produce cleistogamous flowers, and they are generally regarded as self-pollinating, although cross-pollination cannot be completely ruled out (Walton 1982; Parnikoza et al. 2011). According to Walton (1982), C. quitensis could be fertilized by wingless insects which abundantly colonized the flowers of the analyzed species on Signy Island. Many Arctic plants are self-pollinating, in particular in regions with extreme climate, but cross-fertilization with foreign pollen carried by wind and insects is also frequently observed (Bell and Bliss 1980). 
According to Molau (1993), various generative reproduction strategies of Arctic and Alpine vascular plants are linked with their flowering phenology and the persistence of snow cover in the local habitat. The above author analyzed the reproductive traits of 137 Arctic and Subarctic-Alpine species and divided the flowering plants of the Arctic tundra into two categories. The first category comprises species that flower in spring and early summer and colonize habitats where snow cover melts relatively rapidly. Those plants reproduce by crossfertilization and have a low ratio of the number of developed seeds to the number of ovules (Molau 1993). The second category covers species that flower in late summer and grow in habitats with persistent snow cover. Those plants are largely self-pollinating and highly fertile, but their seed development can be inhibited due to adverse weather in final stages of the growing season. Apomixis, a modified form of sexual reproduction where certain stages of the reproductive process are shortened, is often observed in this category of plants (Koltunow 1993). Accelerated reproduction can speed up seed development and maturation before the end of the short growing season in the Arctic (Hörland et al. 2011).

\section{Materials and Methods}

Plant material. - Three species of polar flowering plants of the family Caryophyllaceae were studied. Two species, Cerastium alpinum L. and Silene involucrata, were obtained from the Arctic region, whereas Colobanthus quitensis was harvested in Antarctica. Flower buds at different stages of development and mature diaspores were harvested in the area of the H. Arctowski Polish Antarctic Station $\left(62^{\circ} 09.8^{\prime} \mathrm{S}\right.$ and $\left.58^{\circ} 28.5^{\prime} \mathrm{W}\right)$ and the S. Siedlecki Polish Polar Station in Hornsund, Spitsbergen ( $77^{\circ} 00^{\prime} \mathrm{N}$ and $\left.15^{\circ} 33^{\prime} \mathrm{E}\right)$. The material was collected during Australian and Arctic summer during polar expeditions of 2009-2012 organized by the Department of Antarctic Biology of the Polish Academy of Sciences in Warsaw. Flower buds were chemically fixed upon harvest, and mature diaspores were preserved and dried before transport. Live plants were collected on the day of departure and transported to Poland in plastic containers. Diaspores of Cerastium arvense L. plants harvested in the area of Olsztyn $\left(53^{\circ} 77.9^{\prime} \mathrm{N}\right.$ and $\left.20^{\circ} 48.9^{\prime} \mathrm{E}\right)$ were used in selected experiments for comparative purposes.

Polar plants of Caryophyllaceae grown in a greenhouse. - Polar flowering plants have been grown in the greenhouse of the Faculty of Biology and Biotechnology of the University of Warmia and Mazury in Olsztyn since 2002. The greenhouse collection was started with entire Caryophyllaceae and Poaceae plants and diaspores harvested during polar expeditions. The collection is regularly refreshed by sowing, vegetative propagation and planting of specimens 
transported from polar regions. Plants are grown at a temperature of $18-22^{\circ} \mathrm{C}$ in pots filled with a 2:1 mixture of hortisol and sand. Most plants produce flowers and viable seeds.

Micromorphological observations of diaspores under a light microscope (LM) and a scanning electron microscope (SEM). - Whole mature and dried seeds of Cerastium alpinum, Colobanthus quitensis and Silene involucrata, harvested in the Arctic and Antarctica, and Cerastium arvense harvested in the Olsztyn area, were used in observations. Before examination under a scanning electron microscope, diaspores were mounted on an aluminium holder and sprayed with gold powder in the JEOL JFC-1200 fine coater. The microstructure of diaspore surfaces was observed under the JEOL JSM-5310LV scanning electron microscope at $15-20 \mathrm{kV}$. Images were registered digitally with the use of Thermo Scientific NSS Noran System 7 software. Diaspores were also viewed under the Nikon SMZ 1500 stereomicroscope, and digital images were acquired with the use of the Nikon NIS-Elements BR application.

Histological (LM) and ultrastructural analyses under a transmission electron microscope (TEM). - Flower buds at different stages of development and mature seeds of plant species harvested in polar regions and grown in a greenhouse were used in anatomical and ultrastructural examinations. Flower buds (at harvest) and seeds (after 12 hours of imbibition) were fixed in $4 \%$ glutaraldehyde solution or a mixture of $4 \%$ formaldehyde and $1.25 \%$ glutaraldehyde in a phosphate buffer with $\mathrm{pH}$ 7.0-7.2. Secondary fixation was performed in $2.5 \%$ osmium tetroxide solution. The material was dehydrated in a graded series of alcohols and acetone, saturated in PolyBed 812 epoxy resin and embedded in pure resin. After resin polymerization, semi-thin and ultra-thin sections were cut with the use of Diatome glass and diamond knives in the Ultracut R (Leica) ultramicrotome.

Semi-thin sections $(1.5 \mu \mathrm{m}$ in thickness) were mounted on slides, stained with $1 \%$ toluidine blue, embedded in glycerin and examined under the Nikon Eclipse 80i fluorescence microscope. Images were registered with the use of the Nikon Digital Sight digital camera and NIS-Elements Advanced Research software.

Ultra-thin sections (60-90 nm in thickness) were mounted on 300-mesh copper grids. They were contrasted with a saturated aqueous solution of uranyl acetate and a saturated aqueous solution of lead citrate. Specimens were viewed under the JEOL 1400 transmission electron microscope at $80 \mathrm{kV}$. Electronograms were registered digitally with the use of the Olympus iTEM-TEM imaging system. 
Measurement of diaspore biometric parameters. - One hundred manually separated seeds were weighed on the Radwag MYA 3Y microscales (to the nearest $0.01 \mathrm{mg}$ ) in eight replications to determine 1000 seed weight. The result for every replication was multiplied by 10 . Arithmetic means (X), standard deviations (SD) and coefficients of variation (V\%) were calculated.

One hundred seeds of each species were sampled to determine their geometric parameters. Each seed was measured to determine its length, width and slenderness (length-width ratio). Length and width were measured to the nearest $1 \mu \mathrm{m}$ under the Nikon SMZ 1500 stereomicroscope with the use of the Nikon NIS-Elements BR image application. Arithmetic means $(\mathrm{X})$, standard deviations (SD) and coefficients of variation $(\mathrm{V} \%)$ were calculated for each parameter. The species, date and place of harvest, and the analyzed parameters of the examined seeds are presented in Table 1.

\section{Results}

Development and morphology of generative structures in polar Caryophyllaceae plants. - In their natural habitats, the examined polar species of the family Caryophyllaceae - Colobanthus quitensis (Figs 1a, b), Cerastium alpinum and Silene involucrata - produce flowers that develop into dry fruit - seed capsules that split upon maturation. Greenhouse-grown specimens also produce flowers and fruit (Figs 1d-s). Unlike most Antarctic plants which produce cleistogamous flowers, greenhouse-grown $C$. quitensis had chasmogamous flowers. Similarly to individuals growing in their natural habitats, the flowers of $S$. involucrata plants, propagated from material harvested in the Arctic, were set on long pedicels (several centimeters in length). In successive stages of growth, $S$. involucrata produced flowers that were set directly on the shoot or on short pedicels (Figs 1o, r).

Small, bisexual flowers of $C$. quitensis grow individually at the top of modular shoots, on short pedicels in leaf corners. The perianth is undifferentiated, green (Figs 1d-f) and composed of unfused elements. A single pistil with a large, pear-shaped ovary and a short style (Fig. 1i) ends in five stigma. The androecium is usually composed of six stamens with thecae located at stigma level. Much larger bisexual flowers of $C$. alpinum and S. involucrata are differentiated at the top of the shoot (Figs $1 \mathrm{j}-\mathrm{m}, \mathrm{o}$ ) or in leaf corners, individually or in groups of two or three. They have varied perianths (Figs $1 \mathrm{k}-\mathrm{m}, \mathrm{o}-\mathrm{r}$ ) composed of five hairy calyx lobes and five white petals. In C. alpinum, calyx lobes are not fused (Fig. 11), whereas the sepals of the calyx in $S$. involucrata are fused (Fig. 1p). In C.alpinum and S. involucrata, the androecium is composed of 10 stamens; a single pistil with a short style ends 


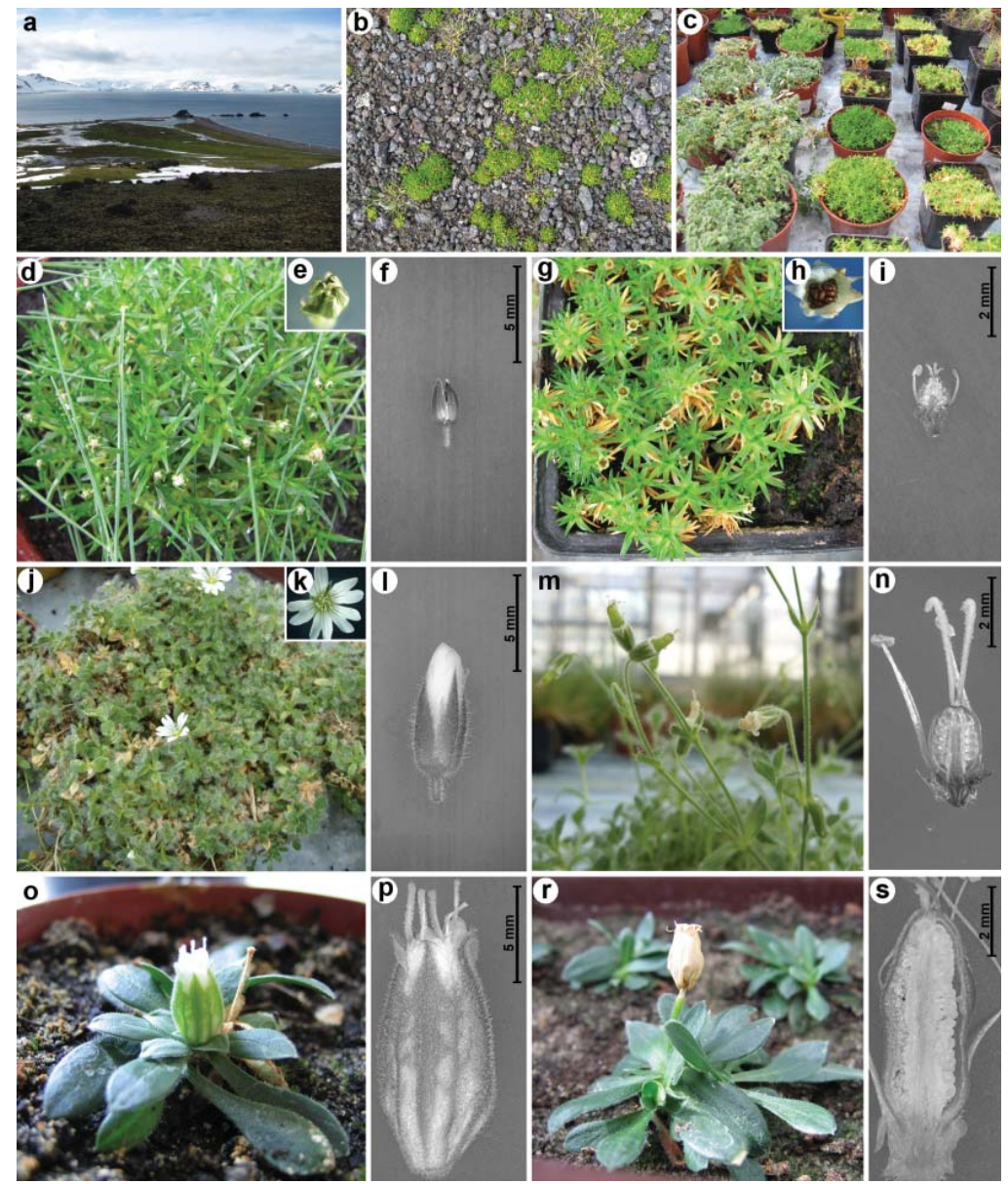

Fig. 1. Polish H. Arctowski Antarctic Station in the Admiralty Bay region (a) and morphology of analyzed species; Colobanthus quitensis plants growing in Antarctica (b), and in a greenhouse (c-i), Cerastium alpinum $(\mathrm{c}, \mathrm{j}-\mathrm{n})$ and Silene involucrata plants growing in a greenhouse $(\mathrm{o}-\mathrm{s})$. $\mathbf{a}$ and $\mathbf{b}$. In the Antarctic tundra $C$. quitensis plants are growing in a wet, fertile habitat at sea level (a) and in a several dozen meters from the Admiralty Bay (b). c. Plants of analyzed species grown in a greenhouse, at $18-20^{\circ} \mathrm{C}$. d-f. Developing bud of hermaphroditic flowers of C. quitensis. $\mathbf{g}$ and $\mathbf{h}$. Brown mature seeds in open capsules of C. quitensis. i. Generative organs of C. quitensis flower with a large, pear-shaped ovary. Longitudinal section of the ovary with a centrally positioned placenta and ovules, two stamina (of the six most frequently differentiated stamina) and three stigmas (of the five most visible stigmas). $\mathbf{j}$ and $\mathbf{k}$. Rapidly growing $C$. alpinum shoots with single pentamerous flowers. White corolla with five long petals and a deep groove in the perianth. l. Flower bud of C. alpinum. Densely hairy calyx sepals with a white and rolled corolla. m. Developing (green) capsules of $C$. alpinum, twice longer than the gamosepalous calyx with 10 sepals. n. Longitudinal section of the ovary of $C$. alpinum with numerous ovules a centrally (axially) positioned placenta, two stamina (of the five most frequently differentiated stamina) and two stigmas (of the five most visible stigmas). $\mathbf{o}$ and $\mathbf{p}$. Developing flower of $S$. involucrata on a significantly shortened shoot (without pedicels). The plants were grown from seeds sown in a greenhouse in Olsztyn. r. Maturing capsule of S. involucrata on a short shoot. s. Longitudinal section of the ovary of S. involucrata.

Highly numerous (white) ovules in an axially positioned placenta. 
in five stigma, and ovules are differentiated from a centrally located placenta (Figs 1i, 1n, 1s). The ovaries of $C$. quitensis and C. alpinum produce several to several dozen ovules, and the strongly elongated ovary of $S$. involucrata produces even hundreds of ovules.

Microsporangia, microspores and male gametophytes. - Four wall layers: epidermis, endothecium, intermediate layer and tapetum, as well as centrally positioned archesporial tissue whose cells undergo meiosis, are differentiated in the microsporangia of all three analyzed species of the family Caryophyllaceae. Male gametophytes differentiate from microspores in successive stages of development.

Elongated epidermal cells, which are parallel to the long axis of the microsporangium, constitute the outermost layer of the thecal wall in all analyzed species (Figs 2a, b, d, i, j, ep). The mechanical endothecium layer is located directly under the epidermis, and it is underlain with the intermediate layer. In early stages of thecal development, the endothecium was composed of parenchymal tissue, whereas characteristic thickening of the walls was observed in the final stage of differentiation when endothecium was transformed into mechanical tissue (Figs 2a, b, d, e, i, j, en).

The pollen chamber was lined with secretory tapetal cells which degenerated upon the maturation of pollen grains (Figs 2a, b, d, e, i, j, ta). In the mature and open thecae of $C$. quitensis and Silene involucrata, the only remnants of tapetal tissue were small granules intensely stained with toluidine blue (Figs 2a, $\mathrm{b}, \mathrm{i}, \mathrm{j}$, arrowheads). In the open thecae of $C$. alpinum filled with germinating pollen grains, tapetal tissue was present in the form of cytoplasm fragments with numerous follicles (Figs 2e, ta). The presence of completely disorganized tapetal cells was observed in infrequent developing thecae of C. alpinum (Fig. 2d).

Nearly all $C$. quitensis microspores formed three-celled male gametophytes. C. quitensis plants harvested in Antarctica had a very small number of microspores and pollen grains per loculus (Fig. 2a).

The grain pollen sporoderm of the evaluated Caryophyllaceae plants featured two distinctive layers of exine and intine. Exine was thick and osmiophilic, whereas intine was thinner and bright. Exine was further divided into sculpted sexine and smooth nexine (Figs 2c, ex, in, se, me). Deposits of granular, osmiophilic material were observed in caverns formed by fused columellae in both C. quitensis and C.alpinum (Fig. 2c, arrowheads). All evaluated Caryophyllaceae plants had polyporate pollen grains whose apertures were covered with intine and nexine (Figs 2b, c, e, h, m, ap).

Mature and split microsporangia of $C$. quitensis contained trinucleate gametophytes where two sperm cells were located near the nucleus of a vegetative cell (Figs 2c, f, g, k, 1). Pollen grains germinated on stigma cells (Fig. 2h) and inside pollen sacs (Figs 2i, j). 


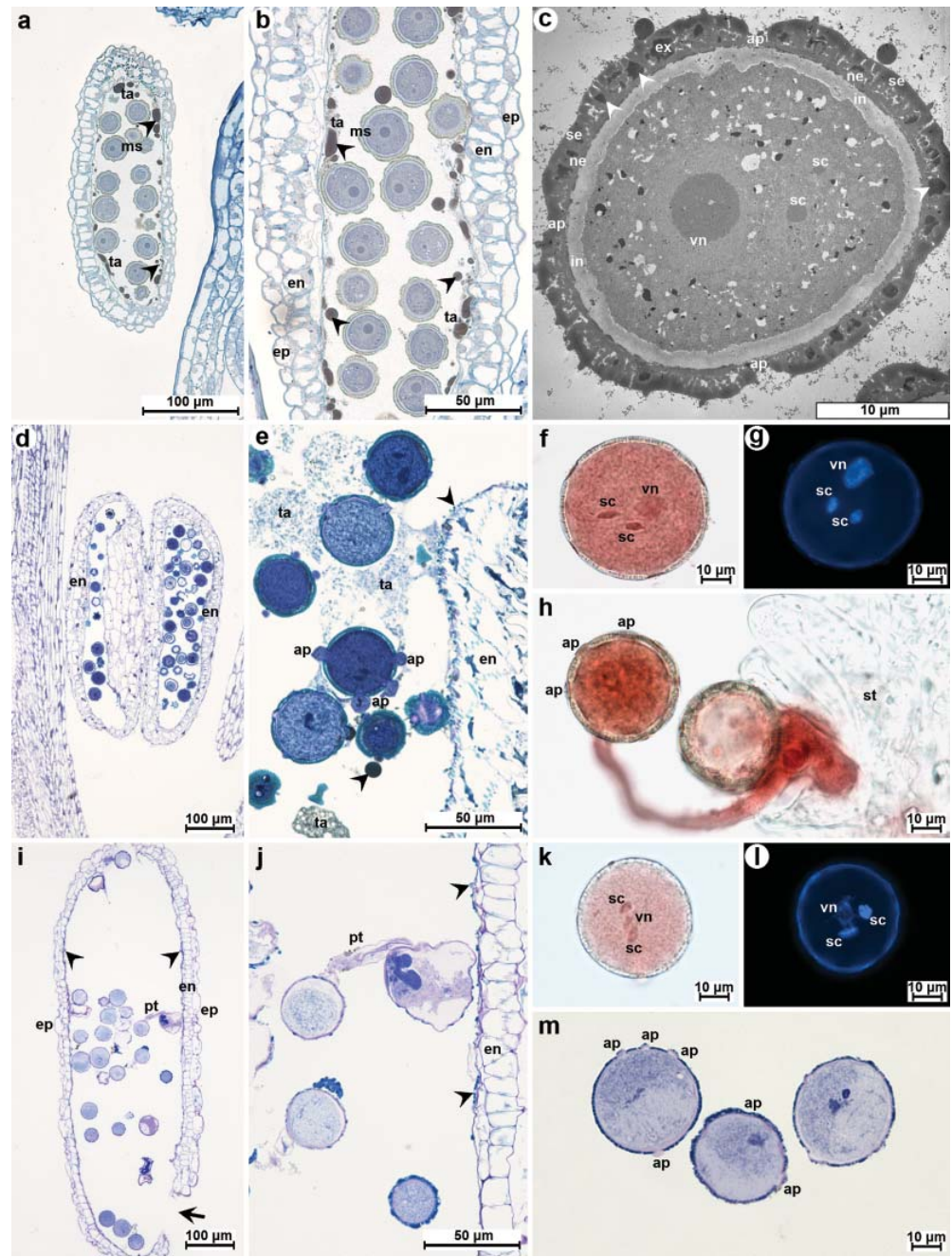

Fig. 2. Developmental stages of Colobanthus quitensis (a-c), Cerastium alpinum $(\mathrm{d}-\mathrm{h})$ and Silene involucrata $(\mathrm{i}-\mathrm{m})$ pollen grains in the anthers. a and b. Longitudinal sections of the microsporangium of an C. quitensis plant growing in Antarctica. Sparse microspores (ms) in the loculus surrounded by thick layer of tapetal tissue (ta, arrowheads), intermediate layers, endothecium (en) and epidermis (ep). Semithin sections stained with toluidine blue. c. Ultrastructure of the tricellular pollen grain of a C. quitensis plant growing in Antarctica. Vegetative nucleus (vn) and sperm cells (sc) of a male gametophyte of $C$. quitensis in the protoplast. Distinctive (osmiophilic) exine (ex) comprising the outer sexine (se), inner nexine (ne) and a weakly osmiophilic (polysaccharide) intine (in). Ultrathin section examined by TEM. d and e. Microspores in a bilocular anther of a greenhouse-grown C. alpinum plant. Monolayered endothecium (en) in the thecal wall facilitates thecal opening and pollen discharge. At the microspore stage, the tapetum is completely disorganized and comprises fragments of "foamy" cytoplasm and drops of osmiophilic material (arrowheads). Pollen grains covered with a thick sporoderm and numerous aperture sites (ap) develop synchronously. Necrotizing cells were observed sporadically. Semithin sections stained with toluidine blue. $\mathbf{f}$ and $\mathbf{g}$. Tricellular mature pollen grains of C. alpinum plants 
growing in a greenhouse. Vegetative nucleus (vn) and sperm cells (sc) of a male gametophyte in the protoplast. Material in toto stained with acetic Carmine (f) and with DAPI (g). h. Germinating pollen grains on the stigma (st) in C. alpinum plants growing in a greenhouse. Material in toto stained with acetic Carmine. $\mathbf{i}$ and $\mathbf{j}$. Tricellular pollen grains in the anther of a greenhouse-grown $S$. involucrata plants. Anther with a broken wall at the stomium site (arrow). Germinating pollen grains inside the microsporangium. Pollen tube (pt) emerging through a distinctively larger aperture site of a polyaperturate pollen grain. Sheathed pollen grains on sporoderm surface. Thecal wall layers, epidermis (ep), endothecium (en), layer of parenchymal cells (intermediate) and tapetum residues (arrowheads). Semithin sections stained with toluidine blue. $\mathbf{k}$ and $\mathbf{l}$. Tricellular mature pollen grains of $S$. involucrata plants growing in a greenhouse. Vegetative nucleus (vn) and sperm cells $(\mathrm{sc})$ of a male gametophyte in the protoplast. Material in toto stained with acetic Carmine (k) and with DAPI (1). m. Polyaperturate (ap), mature pollen grains of $S$. involucrata plants growing in a greenhouse. Semithin sections stained with toluidine blue.

Morphology of ovules. - In the analyzed species of Caryophyllaceae plants, ovules with thick nucelli had two integuments, where the inner integument was differentiated before the outer integument (Figs 3a, b, e). The integuments grew simultaneously with the embryo sac, the wide ends of the inner integument were close to one another upon the maturation of the embryo sac, and they formed a micropylar canal in successive stages of development. Numerous organelles, mostly starch-filled chloroplasts, were visible during the development and maturation of seeds in all analyzed species. Cell vacuolization was accompanied by the accumulation of large and dark (osmiophilic) inclusions in the outer layer of the outer integument and the inner layer of the inner integument (Figs 3b,e, h).

Large nucelli contained dense cytoplasm and granulose cells with numerous organelles, variously shaped mitochondria and chloroplasts with dense, osmiophilic content. Upon the maturation of the embryo sac, the ovules of C. quitensis accumulated starch reserves, mostly in the chalazal region. After fertilization and during the development of the pre-embryo, starch reserves were also noted in lateral and micropylar segments of the ovule (Figs 3b, pe). Storage reserves were not accumulated in the nucelli of $C$. alpinum or S. involucrata in corresponding developmental stages (Figs 3e, h, i).

In the ovules of all examined Caryophyllaceae plants, megaspore tetrads were differentiated from meiotically dividing megasporocytes, and functional megaspores formed embryonic sacs of monosporous Polygonum type. The egg apparatus in $C$. quitensis, C. alpinum and S. involucrata was composed of an egg cell and two synergids with a distinctive and well-developed filiform apparatus. Polarization was observed in all three cells of the egg apparatus. In the ovule of $S$. involucrata, the filiform apparatus was differentiated at the top of synergids, and a large nucleus with a nucleolus were visible in the chalazal region of the egg cell (Figs 3a, e, i, ea, ec, sy). Synergid activity was clearly differentiated - one synergid accumulated reserve substances, and symptoms of degeneration were observed in the other (Fig. 3i, arrow, arrowhead). 


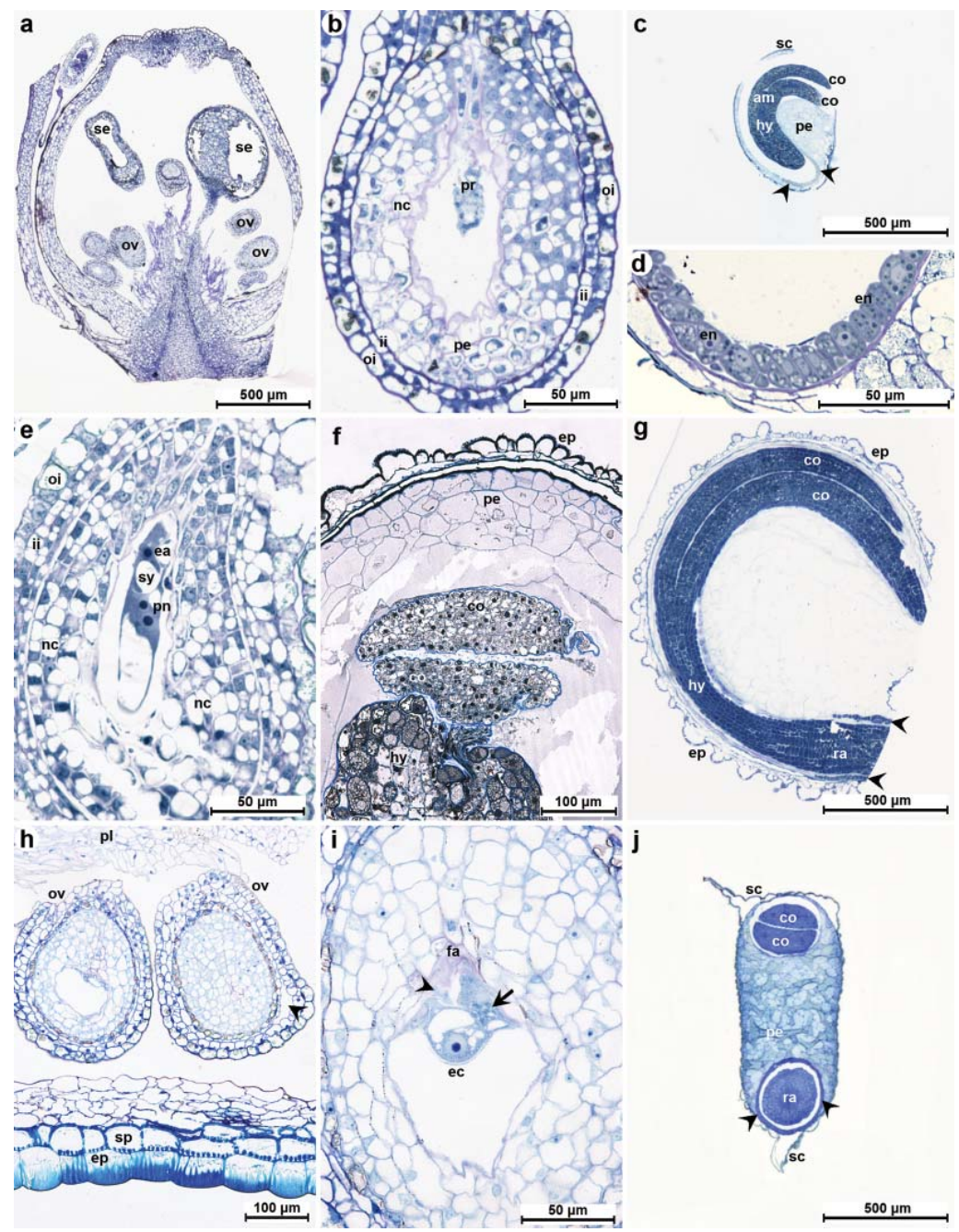

Fig. 3. Developing ovules and seeds in a flower buds of a Colobanthus quitensis (a-d), Cerastium alpinum $(\mathrm{e}-\mathrm{g})$ and Silene involucrata $(\mathrm{h}-\mathrm{j})$. Semithin sections stained with toluidine blue. a. Flower bud of a C. quitensis plant from Antarctica. Developing seeds (se) and less developed ovules (ov) in a longitudinal sections of the ovary. b. Developing proembryo (pr) and disorganization of protoplasts in nucellus cells (nc). Accumulation of lipid material in integument cells (in particular in the outer integument - oi). c. Anatomy of seed of a greenhouse-grown C. quitensis plant. Seed coat (sc) and a fragment of perispermium (pe), micropylar endosperm (arrowhead), embryonic shoot with an apical meristem (am), cotyledons (co) and a hypocotyl (hy). d. Part of the micropylar endosperm (en) in a C. quitensis seed. e. Anatomy of an ovule and the embryo sac of a greenhouse-grown C. alpinum plant. Cells of the egg apparatus (ea) in the micropylar region of an anatropous ovules. Synergids (sy) and polar nuclei (pn) with distinctive nucleoli in the central part of the embryo sac in the cytoplasm of a central cell. Differentiated layers of outer (oi) and inner (ii) integument cells and nucellus cells (nc). f. Part of C. alpinum seed crosssection along a plane perpendicular to the micropylar-chalazal axis. Visible testa with differentiated epidermal cells (ep), perisperm tissue (pe), embryonic cotyledons (co) and hypocotyls (hy). 
g. C. alpinum seed cross-section along the shoot-root axis. Section of the root surrounded by micropylar endosperm (arrowheads). h. Anatomy of crassinucellate anatropous ovules (ov) of a greenhouse-grown $S$. involucrata plant. Ovules in the ovary chamber between placental tissue (pl) and the ovary wall, covered with epidermal (ep) and subepidermal (sp) cells with thickened walls. i. Egg cell (ec) with typical polarity; cell nucleus positioned at the chalasal region, and vacuoles - at the micropylar end of the egg cell. One synergid actively accumulates reserve material (arrows), and the other synergid shows clear symptoms of degeneration (arrowhead). Filiform apparatus (fa) of a synergid. j. Anatomy of seed of a S. involucrata plant growing in the Arctic. Seed cross-section along a plane perpendicular to the micropylar-chalazal axis. Seed coat (sc) with characteristic protrusions, perpendiculary incised, embryonic cotyledons (co), a radicle (ra) and micropylar endosperm (arrowheads) surrounding the radicle of a peripherally positioned embryo. Perisperm tissue (pe) is composed of cells filled with starch granules.

In the cytoplasm of the central cell in C. alpinum, polar nuclei (Fig. 3e, pn) and reserve substances identical to those found in the nucellus were visible in the vicinity of the egg apparatus (Fig. 3e, nu).

In the analyzed plants, ovules developed synchronously, but ovaries with developing seeds and less developed ovules were observed in selected flower buds of C. quitensis harvested in the Antarctic (Fig. 3a, ov, se).

Diaspore anatomy. - The seeds of the analyzed Caryophyllaceae species were composed of testa, perisperm (nutritive tissue), small amounts of endosperm and a curved, peripherally located embryo (Figs 3c, d, g, j). In mature diaspores, embryos had well developed organs: the apical meristem, two cotyledons, the hypocotyl-root axis and the radicle (Figs 3c, g, j, am, co, hy, ra). In mature seeds of the examined Caryophyllaceae, the radicle was surrounded by micropylar endosperm composed of a single layer of uniformly sized cells (Figs 3c, d, $\mathrm{g}, \mathrm{j}$, en, arrowheads). In C. quitensis, endosperm cells were filled with dense cytoplasm, organelles and osmiophilic droplets (Fig. 3d, en). The perisperm filled nearly $50 \%$ of the analyzed seeds. In mature seeds, perisperm cells contained mostly starch granules.

In the examined Caryophyllaceae species, testae were composed of modified cells of outer and inner integuments. The degree of cell aggregation and cell anatomy differed in various parts of the seed. In C. quitensis, two cell layers were visible in an area differentiating from the chalazal region (Figs 3b, ii, oi). Outer integument cells had thick and well-filled outer adjacent walls and much thinner inner adjacent and radial walls.

In $C$. alpinum, the seed coat was made up of two layers: the outer testa and the inner tegmen (Figs 3e-g, ii, oi, ep). Testa cells varied in shape. The outermost cells had thick outer adjacent and radial walls. Tegmen cells were flat, they had thin walls and were filled with osmiophilic material.

In S. involucrata seeds, the testa was composed of two cell layers. The thicker outer layer comprised isodiametric cells. Stratification of testa was observed in 
certain regions of $S$. involucrata seeds (Figs $3 \mathrm{~h}, \mathrm{j}$, sc, arrowhead). Large-cell protrusions were observed on the testa, perpendicular to the micropylar-chalazal axis at the level of the hypocotyl (Fig. 3j, sc).

Seed size and 1000 seed weight. - The analyzed Caryophyllaceae plants are characterized by very small seeds (Table 1). Colobanthus quitensis produces particularly small seeds, $0.6-0.7 \mathrm{~mm}$ in length and $0.4-0.5 \mathrm{~mm}$ in width. C. quitensis seeds harvested in two growing seasons in Antarctica had similar dimensions (Table 1). Cerastium alpinum and Silene involucrata produce somewhat larger seeds than $C$. quitensis. Average seed length and seed width reach $0.995 \mathrm{~mm}$ and 0.846 , respectively, in C. alpinum, and $1.050 \mathrm{~mm}$ and $1.180 \mathrm{~mm}$, respectively, in S. involucrata. The seeds produced by Cerastium arvense plants harvested in the Olsztyn area, characterized by an average length of $0.717 \mathrm{~mm}$ and an average width of $0.695 \mathrm{~mm}$, were smaller than the seeds of the analyzed Caryophyllaceae species from the Arctic, but larger than the seeds of the Antarctic C. quitensis. The greatest differences in seed length and seed width, confirmed by the highest values of coefficients of variation, were observed in S. involucrata (Table 1).

The seed length to seed width ratio revealed that $C$. quitensis produced the most elongated seeds, whereas $S$. involucrata - the least slender seeds (Table 1). The average length to width ratio was somewhat higher in $C$. alpinum than in $C$. arvense seeds, but maximum and minimum values of the ratio were determined in the same range of 0.81 to 1.44 in both species.

$C$. quitensis seeds were characterized by the lowest weight and the smallest dimensions in the analyzed group of Caryophyllaceae plants. The 1000 seed weight of $C$. quitensis seeds did not differ significantly between batches of material harvested in growing seasons of 2009/2010 and 2011/2012, and it was determined at $50.8 \mathrm{mg}$ and $53.3 \mathrm{mg}$, respectively. The 1000 seed weight of the remaining seeds was at least twice higher. S. involucrata produced the largest, but not the heaviest seeds (Table 1). The 1000 seed weight was highest in the Arctic species of C. alpinum (214.6 mg), and it was nearly half lower $(115.5 \mathrm{mg})$ in $C$. arvense.

Shape and micromorphological parameters of seeds. - The seeds of the analyzed Caryophyllaceae plants were laterally flattened and kidney-shaped. C. quitensis produced triangular seeds which were narrower in the region of the radicle and wider near the cotyledons (Figs $4 \mathrm{a}-\mathrm{c}$ ). C. alpinum seeds were somewhat angular, sometimes spherical, whereas $C$. arvense seeds were generally more angular. Seeds produced by plants of the genus Cerastium were trapezoid in shape (Figs 4e, f, m, n). 
Table 1

Arithmetic means (X), standard deviations (SD) and coefficients of variation (V\%) for biometric parameters of seeds produced by the four examined Caryophyllaceae species. The data for $C$. quitensis refer to seeds harvested in two growing seasons.

\begin{tabular}{|c|c|c|c|c|c|c|}
\hline Species & Season & Index & $\begin{array}{c}1000 \text { seed } \\
\text { weight }[\mathrm{mg}]\end{array}$ & $\begin{array}{c}\text { Length } \\
{[\mathrm{mm}]}\end{array}$ & $\begin{array}{l}\text { Width } \\
{[\mathrm{mm}]}\end{array}$ & Slenderness \\
\hline \multirow{2}{*}{$\begin{array}{l}\text { Colobanthus } \\
\text { quitensis }\end{array}$} & $2009 / 10$ & $\begin{array}{c}X \\
\text { SD } \\
\text { V\% }\end{array}$ & $\begin{array}{c}\mathbf{5 0 . 8} \\
\pm 1.7 \\
3.3\end{array}$ & $\begin{array}{c}\mathbf{0 . 6 5 3} \\
\pm 0.044 \\
6.76\end{array}$ & $\begin{array}{c}\mathbf{0 . 4 8 1} \\
\pm 0.036 \\
7.46\end{array}$ & $\begin{array}{c}\mathbf{1 . 3 6} \\
\pm 0.11 \\
7.8\end{array}$ \\
\hline & 2011/12 & $\begin{array}{c}X \\
\text { SD } \\
\text { V\% }\end{array}$ & $\begin{array}{c}\mathbf{5 3 . 3} \\
\pm 2.3 \\
4.3\end{array}$ & $\begin{array}{c}\mathbf{0 . 6 3 6} \\
\pm 0.042 \\
6.57\end{array}$ & $\begin{array}{c}\mathbf{0 . 4 8 5} \\
\pm 0.032 \\
7.46\end{array}$ & $\begin{array}{c}\mathbf{1 . 3 1} \\
\pm 0.08 \\
6.4\end{array}$ \\
\hline $\begin{array}{l}\text { Cerastium } \\
\text { alpinum }\end{array}$ & 2012 & $\begin{array}{c}X \\
\text { SD } \\
\text { V\% }\end{array}$ & $\begin{array}{c}\mathbf{2 1 4 . 6} \\
\pm 2.5 \\
1.2\end{array}$ & $\begin{array}{c}\mathbf{0 . 9 9 5} \\
\pm 0.103 \\
10.40\end{array}$ & $\begin{array}{c}\mathbf{0 . 8 4 6} \\
\pm 0.085 \\
10.10\end{array}$ & $\begin{array}{c}\mathbf{1 . 1 8} \\
\pm 0.11 \\
9.3\end{array}$ \\
\hline Silene involucrata & 2010 & $\begin{array}{c}X \\
\text { SD } \\
\text { V\% }\end{array}$ & $\begin{array}{c}\mathbf{1 7 1 . 6} \\
\mathbf{+} 3.1 \\
1.8\end{array}$ & $\begin{array}{c}\mathbf{1 . 0 5 0} \\
\pm 0.167 \\
15.92\end{array}$ & $\begin{array}{c}\mathbf{1 . 1 8 0} \\
\pm 0.168 \\
14.26\end{array}$ & $\begin{array}{c}\mathbf{0 . 9 0} \\
\pm 0.13 \\
15.0\end{array}$ \\
\hline $\begin{array}{l}\text { Cerastium } \\
\text { arvense }\end{array}$ & 2010 & $\begin{array}{c}X \\
\text { SD } \\
\text { V\% }\end{array}$ & $\begin{array}{c}\mathbf{1 1 5 . 5} \\
\pm 2.1 \\
1.9\end{array}$ & $\begin{array}{c}\mathbf{0 . 7 1 7} \\
\pm 0.060 \\
8.36\end{array}$ & $\begin{array}{c}\mathbf{0 . 6 9 5} \\
\pm 0.063 \\
9.11\end{array}$ & $\begin{array}{c}\mathbf{1 . 0 4} \\
\pm 0.11 \\
10.5\end{array}$ \\
\hline
\end{tabular}

The shape of S. involucrata seeds ranged from kidney to angular. A winglike protrusion (Figs $4 \mathrm{i}, \mathrm{j}$ ) composed of several, usually three to five convex epidermal cells, was observed on the dorsal side.

Mature seeds of all examined Caryophyllaceae species were brown. Under a scanning electron microscope, the surface of $C$. quitensis seeds was smooth and lustrous (Figs $4 \mathrm{a}-\mathrm{c}$ ), whereas the surface of seeds produced by plants of the genus Cerastium was strongly verrucous and matte in appearance (Figs $4 \mathrm{e}-\mathrm{g}, \mathrm{m}-\mathrm{O}$ ).

Testa epidermal cells of $C$. quitensis cells were elongated, with flat periclinal walls and folded and S-shaped anticlinal walls. Delicate and irregular secondary ornamentation, thickened along the edges, was observed on the surface of periclinal walls (Fig. 4d).

Epidermal cells of S. involucrata were characterized by collapsed and folded $\mathrm{U}$ - and V-shaped anticlinal walls as well as convex and partially collapsed periclinal walls. Fine, verrucous secondary sculptures were observed on the surface of periclinal walls (Figs $4 \mathrm{k}, 1$ ).

In seeds of the genus Cerastium, testa epidermal cells were star-shaped (Figs $4 \mathrm{~g}, \mathrm{~h}, \mathrm{o}, \mathrm{p}$ ). Periclinal walls in the epidermis of $C$. alpinum and C. arvense seeds were strongly convex, and anticlinal walls were collapsed, folded, Uand V-shaped (Figs 4h, p). Convex periclinal walls in strongly elongated cells 

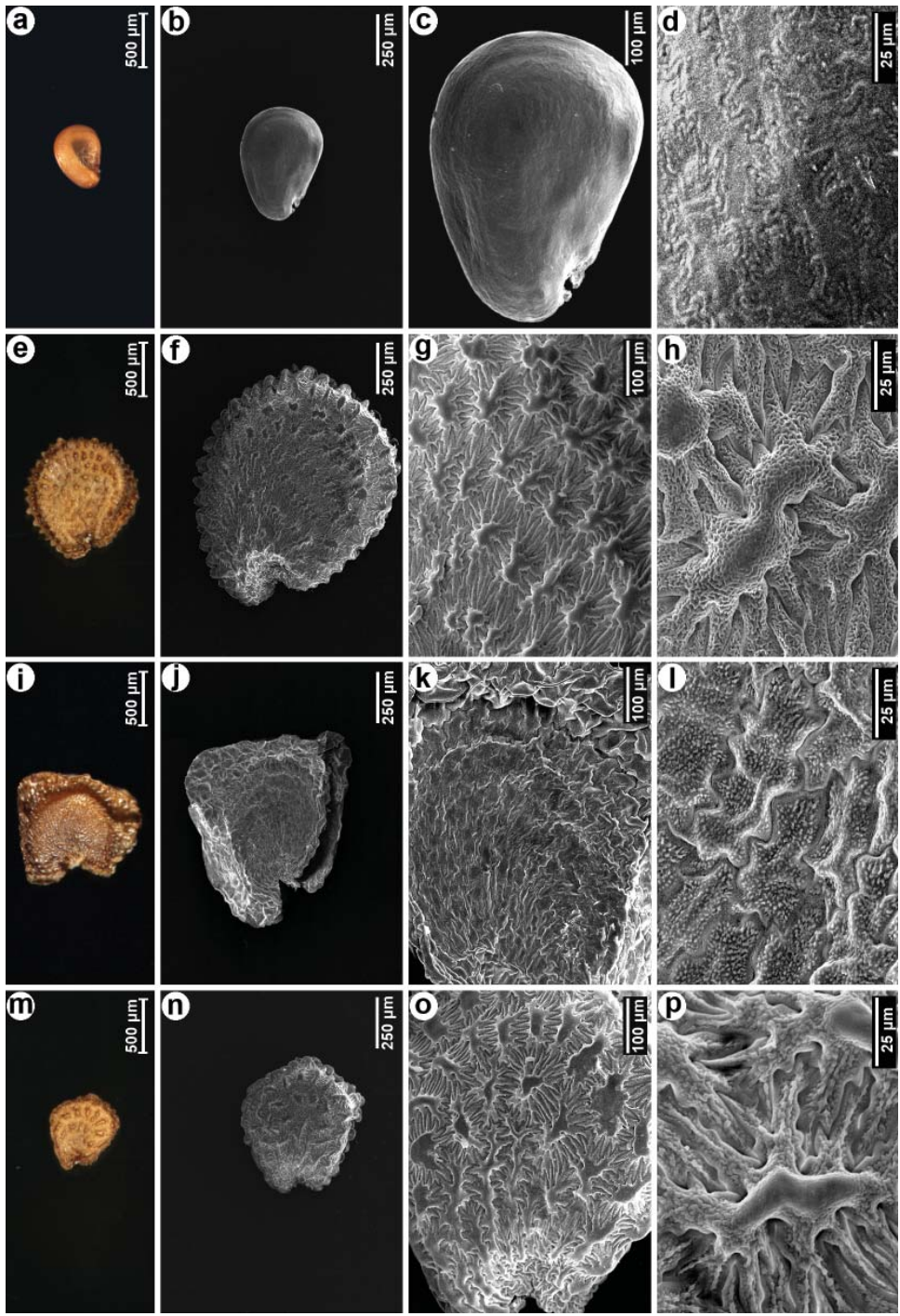

Fig. 4. Seed epidermis micromorphology of a Colobanthus quitensis plant growing in Antarctica (Figs 4. a-d), Cerastium alpinum (Figs 4. e-h) and Silene involucrata plants growing in the Arctic (Figs i-1), and Cerastium arvense plant growing near Olsztyn (Figs 4. m-p: a, e, i and $\mathrm{m}-$ images examined by LM; $\mathrm{b}-\mathrm{d}, \mathrm{f}-\mathrm{h}, \mathrm{j}-\mathrm{-}$ and $\mathrm{n}-\mathrm{p}-$ images examined by SEM. a. Colobanthus quitensis seed with distinctive contours of peripherally positioned embryo. b. and c. Smooth and glossy, without hairs or protrusions surface of a C. quitensis seed. d. Surface microstructure of a $C$. quitensis seed. Elongated testa epidermal cells with folded, S-shaped anticlinal walls, and periclinal walls covered with small, irregular nodes, with a clearly thickened secondary sculpture along the edges. e. Cerastium alpinum seed with distinctive contours of a peripherally positioned embryo. f.-g. Testa epidermal surface with distinctive sculpture of periclinal walls. h. Elongated testa epidermal cells with folded, U- and V- shaped collapsed anticlinal walls, secondary sculpture of convex periclinal walls covered with small nodules. i. Seed of a $S$. involucrata plant growing in the Arctic. Expanding testa produces a wing-like structure along $3 / 4$ of its circumference. 
j.-k. Surface of the seed and epidermal cells with collapsed anticlinal walls. I. Epidermal cells with folded, U- and V-shaped collapsed anticlinal walls, sculpture of convex and collapsed periclinal walls covered with small nodules. $\mathbf{m}$. Seed of a $C$. arvense plant growing near Olsztyn with clearly ornamented surface. n.--o. Regular distribution of epidermal cells with collapsed anticlinal walls, secondary sculpture of convex periclinal walls smooth or covered with small nodules.

formed a crest, and they were arranged in the shape of hills in cells with a more oval shape. Periclinal walls formed finger-like protrusions on the dorsal side of seeds. Epidermal periclinal walls in $C$. alpinum had verrucous surface (Fig. 4h). Epidermal periclinal walls in $C$. arvense seeds had partly verrucous sculpture, whereas the remaining, most convex regions had smooth secondary sculpture (Fig. 4p).

\section{Discussion}

Antarctica is characterized by significantly fewer species of flowering plants than the Arctic, and species diversity is both polar regions is much lower in comparison with other regions of the Earth. The key factors that inhibit the growth and development of flowering plants in polar regions are low temperature, low water availability and nutrient-poor soil (Billings 1987; Alberdi et al. 2002; Block et al. 2009). Other environmental hazards include high and largely unpredictable variability in temperature and moisture levels in local habitats (Bliss and Gold 1999; Jónsdóttir 2005; Convey 2012; Chwedorzewska et al. 2014; Giełwanowska et al. 2014, 2015; Giełwanowska and Kellmann-Sopyła 2015).

Polar vascular plants are characterized by a limited number of growth forms (Bliss 1962), which undoubtedly results from adaptation to extreme environmental conditions. The evaluated phanerogams, including the Antarctic Colobanthus quitensis and the Arctic Cerastium alpinum and Silene involucrata, as well as other representatives of polar fauna are small herbaceous plants with compact habit, producing numerous flowers and viable seeds.

The reproductive strategies of flowering plants native to polar regions have been widely discussed in the literature (Müller et al. 2011; Klimešová and Doležal 2012; Chwedorzewska et al. 2014), but the predominant form of reproduction in polar vascular plants has not yet been identified. The significance of vegetative reproduction in polar regions has been emphasized (Edwards 1974; Billings 1987; Pirożnikow 1993), but some authors noted that despite short and cold growing seasons that do not support generative reproduction, some polar vascular plants are capable of producing flowers and inflorescences that develop into fruit with viable seeds (Lewis Smith 1984; Convey 1996; Cooper et al. 2004; Alsos et al. 2013). 
Morphology of generative structures in polar Caryophyllaceae plants

Development and anatomy of the male gametophyte. - In this study, microscopic analyses revealed that Caryophyllaceae produced flower buds with (in most cases) normally developed microsporangia, microspores and male gametophytes. Selected attributes of microsporangia and male germ line cells in Antarctic phanerogams growing in their native habitats were discussed in our previous studies (Giełwanowska et al. 2011).

Microscopic analyses of Arctic flowering plants indicate that similarly to the Antarctic species Colobanthus quitensis, pollen grains of Cerastium alpinum and Silene involucrata reach the trinucleate stage already before pollen dispersal. Some grains do not leave the theca and germinate in microsporangia, whereas in most angiosperms, the theca opens when pollen grains reach the stage of a two-celled male gametophyte, and their generative cells divide into two sperm cells only during the growth of the pollen tube. The production of trinucleate gametophytes in closed microsporangia of Colobanthus quitensis was observed in our earlier study (Giełwanowska et al. 2011). This strategy shortens the period between pollen release and successful fertilization, which minimizes the risk that pollen will be adversely influenced by external factors during its transport to the stigma. It was experimentally proven that threecelled pollen grains accumulate more mRNA and protein than two-celled gametophytes (Linskens 1988). Those compounds are accumulated during pollen maturation and are used up during germination and pollen tube growth. Trinucleate gametophytes which accumulate those substances germinate faster than binucleate gametophytes where mRNA and proteins are synthesized only during germination (Mascarenhas 1989).

Pollen grains of the analyzed Caryophyllaceae species were polyporate and covered by thick sporoderm with species-specific sculpture. In pollen grains of $C$. quitensis and C.alpinum, sexine was composed of columellae and a tectum layer. Pollen grains produced by plant species of the family Caryophyllaceae are generally polyaperturate and characterized by thick sexine with a tectum layer (Bittrich 1993). In pollen grains produced by C.quitensis and C.alpinum, sexine accumulated large amounts of granular osmiophilic material. In $S$. involucrata, the sexine layer also featured crystal-like inclusions, probably proteins, intensely stained with toluidine blue, which could be both enzymes and glycoproteins that regulate pollen specificity in the progamic phase (Castro et al. 2013).

Anatomy of the embryo sac. - In an analysis of the embryo sacs of polar plants belonging to the family Caryophyllaceae, synergids attracted particular attention. The filiform apparatus, through which the pollen tube penetrates the embryo sac in nearly all angiosperm species, including the studied representatives of Caryophyllaceae, was differentiated in the synergids. In the Antarctic species 
C. quitensis, the filiform apparatus is always differentiated in synergids, and it is always well developed in plants growing in their native habitats in the Antarctic and in a greenhouse (Giełwanowska et al. 2011).

Disruptions in the development of thecae and ovules. - Generative organs of flowering plants are particularly sensitive to cold. Low temperatures induce structural and functional changes in plant tissues, which could disrupt fertilization and lead to the degradation of developing seeds. Differences in cold sensitivity have not yet been determined between various stages of generative reproduction, but the existing research suggests that pollen development and fertilization are most susceptible to low temperature (Kelly et al. 2010).

During the growing season, Antarctic plants are exposed to low temperatures and sudden temperature drops of $20-30^{\circ} \mathrm{C}$ on a daily basis (Convey 2012). For this reason, the sporadically observed disruptions in the development of male and female generative structures can probably be attributed to cold and freezing stress.

Early degeneration of the tapetum was relatively frequently noted in the thecae of $C$. quitensis plants harvested in the Antarctic (Giełwanowska et al. 2011). Tapetal tissue protects and nourishes male germ line cells, and its degeneration products are used to rebuild the sporoderm or produce the pollen coat which facilitates pollination. Microspores are particularly sensitive to cold stress in early stages of development, during or directly after release from tetrads (Nishiyama 1984). Over that period, the tapetum is fully developed, and it supplies microspores with nutrients and enzymes.

In most cases, ovules developed synchronously in the ovaries of the analyzed Caryophyllaceae plants, but in selected flower buds of $C$. quitensis from the Antarctic, ovaries also contained large, developing seeds as well as ovules which were several-fold smaller and less developed. Embryo sacs with differentiated cells, i.e. synergids, an egg cell and a central cell, were visible in ovules. The above could indicate that the female gametophyte developed in immature ovules, but it remains unknown whether those ovules continued to develop and produce seeds. Such ovules could be characterized by reduced vitality. The presence of ovules whose vitality was compromised by low temperature has been described in Cicer arietinum L. The above slowed down the growth of pollen tubes in pistil tissues and lowered fertilization success (Srinivasan et al. 1999). Only some ovules with low fertility can be successfully fertilized and produce viable seeds.

Development and anatomy of seeds. - The accumulation of electrondense and variously osmophilic material in the protoplasts of epidermal cells of integuments and their adjacent outer walls was observed during ovule development in the studied Caryophyllaceae plants. The deposits on testa cell 
walls lead to the formation of a hard seed coat which plays an important role in the seed life cycle, in particular after seeds have been separated from the mother plant. The material in exotesta and endotegmen cells in the seeds of Caryophyllaceae plants as well as the accumulated tannins protect seeds against pathogenic fungi (Bittrich 1993).

In the investigated Caryophyllaceae plants, the perisperm occupied a large part of the seeds. The perisperm develops from nucellar cells in the chalazal region, and it constitutes the main nutritive tissue in seeds produced by Caryophyllaceae plants and most plants of the order Caryophyllales. Starch was the major reserve substance in perisperm cells. The endosperm was composed of a single layer of cells only in the micropylar region where it surrounded the radicle. A large, peripherally located embryo occupied nearly one-half of the seed in all analyzed species of polar plants.

Seed morphology in polar plants of the family Caryophyllaceae as an adaptive strategy. - The size and shape of seeds are part of a plant's adaptation strategy to the local environment. All of the analyzed Caryophyllaceae species produce very small and light seeds. The seeds of Cerastium arvense plants growing in the Olsztyn area were similar in size to the seeds of the polar species of $C$. alpinum. Their length and width did not exceed $2 \mathrm{~mm}$, and 1000 seed weight was very low in the range of $50-350 \mathrm{mg}$. According to Tilman (1988), seed size is correlated with the degree of competition for local resources. The cited author observed that fine seeds are produced in nutritionally deficient habitats where light access is not blocked by other plants. Polar regions are nutritionally deficient habitats with negligible competition, and local species produce large numbers of fine seeds, which seems to confirm the hypothesis proposed by Tilman (1988). In numerous studies, the shape and size of seeds produced in extreme habitats was analyzed in view of their longevity and ability to create a soil seed bank. Thompson and Grime (1979) demonstrated that species contributing to soil seed banks produce very small seeds. A similar correlation was reported in 32 grass species in Great Britain (Leck et al. 1989). The seeds of species with a permanent soil seed bank were significantly smaller and more compact than the seeds of other species. Two species of flowering plants native to the Antarctic, Colobanthus quitenis and Deschampsia antarctica (McGraw and Day 1997; Ruhland and Day 2001), and one introduced species Poa апnиa (Wódkiewicz et al. 2013; Chwedorzewska et al. 2014; KellmannSopyła and Giełwanowska 2015), are well represented in the Antarctic soil seed bank, and they provide additional evidence that longevity and the ability to sustain a permanent soil seed bank are characteristic features of fine seeds. The above hypothesis was also confirmed in the Arctic region where more than $50 \%$ of local flora species produce permanent soil seed banks (McGraw and Vavrek 1989; Cooper et al. 2004). The formation of a permanent soil seed bank 
is a vital adaptive trait of flowering plants in polar regions which maximizes the reproductive success of plants in extreme, unstable habitats.

In this study, the observations performed under a scanning electron microscope revealed similarities in the surface microstructure of Caryophyllaceae seeds. Despite the above, the size of epidermal cells, the shape of folds in anticlinal walls, the contour of periclinal walls and the degree of cuticular ornamentation were species-specific. Taxonomic units belonging to the family Caryophyllaceae generally differ significantly in the sculpture of their testae, a parameter that is used to identify and discriminate between species (Fawzi et al. 2010).

The small size and low weight of diaspores in the analyzed Poaceae species indicate that the diaspores of polar plants are dispersed mainly by wind, although the analyzed caryopses were devoid of any structures that would facilitate this form of distribution. The only exception were $S$. involucrata seeds which developed wing-like structures made of a single layer of epidermal cells filled with air.

Zoochory seems to play a minor role in polar flowering plants due to the scarcity of fauna in polar regions, in particular in the Antarctic (Prestrud et al. 2004). According to Kerlick et al. (1986), animals rarely consume fine seeds weighing less than $3 \mathrm{mg}$, therefore zoochory is probably a relatively rare dispersion mechanism in the studied C.alpinum, C. quitensis and S. involucrata.

It remains unknown whether the diaspores of the analyzed Caryophyllaceae species can be effectively transported by water. The results of morphological and ecological studies of eight phanerogams growing on subantarctic Kerguelen Islands indicate that water plays an important role in seed dispersal (Hennion and Walton 1997). According to the above authors, seeds produced by Colobanthus kerguelensis Hook.f. are transported between Kerguelen Island by the sea, although this assumption has not been confirmed. A morphological analysis revealed that C. kerguelensis seeds are highly similar to C. quitensis seeds, which suggests that hydrochory could be an important dissemination mechanism in this species.

Acknowledgments. - We would like to thank our anonymous reviewers and the Polish Polar Research editorial team for their work.

\section{References}

Alberdi M., BraVo L.A., Gutierrez A., GideKel M. and CorCuera L.J. 2002. Ecophysiology of Antarctic vascular plants. Physiologia Plantarum 115: 479-486.

Alsos I.G., MÜLLER E. and EIDESEN P.B. 2013. Germinating seeds or bulbils in 87 of 113 tested Arctic species indicate potential for ex situ seed bank storage. Polar Biology 36: 819-830.

BELL K.L. and BLISS L.C. 1980. Plant reproduction in a high Arctic environment. Arctic, Antarctic and Alpine Research 12: 1-10. 
BILLINGS W.D. 1987. Constraints to plant growth, reproduction and establishment in Arctic environments. Arctic, Antarctic and Alpine Research 19: 357-365.

BILlingS W.D. and Mooney H.A. 1968. The ecology of arctic and alpine plants. Biological Reviews 43: 481-529.

BITTRICH V. 1993. Caryophyllaceae. In: K. Kubitzki, J.G. Rohwer and V. Bittrich (eds). The families and genera of vascular plants. Volume II. Flowering plants. Dicotyledons. Magnoliid, Hamamelid and Caryophyllid Families. Springer Verlag, Berlin, Heidelberg GmbH: 653 pp.

BLISS L.C. 1962. Adaptations of arctic and alpine plants to environmental conditions. Arctic 15: $117-144$.

BLISS L.C. and GOLD W.G. 1999. Vascular plant reproduction, establishment, and growth and the effects of cryptogamic crusts within a polar desert ecosystem, Devon Island, NWT, Canada. Canadian Journal of Botany 77: 623-636.

BLOCK W., LEWIS SMITH R.I. and KENNEDY A.D. 2009: Strategies of survival and resource exploitation in the Antarctic fellfield ecosystem. Biological Reviews 84: 449-484.

Castro A.J., SuÁrez C., Zienkiewicz K., De Dios Alché J., Zienkiewicz A. and Rodriguez-GARCIA M.I. 2013. Electrophoretic profiling and immunocytochemical detection of pectins and arabinogalactan proteins in the olive pollen during germination and pollen tube growth. Annals of Botany 112: 503-513.

Chwedorzewska K.J., GieŁwanowska I., Olech M., Molina-Montenegro M.A., WódKieWICZ M. and GALERA H. 2014. Poa annua L. in the maritime Antarctic: an overview. Polar Record 51: 637-643.

CONVEY P. 1996. Reproduction of Antarctic flowering plants. Antarctic Science 8: 127-134.

CONVEY P. 2012. Polar terrestrial environments. In: E. BELL (ed.) Life at extremes; Environments, organisms and strategies for survival, CABI, United Kingdom: 81-90.

Cooper E.J., Alsos I.G., Hagen D., SMith F.M., Coulson S.J. and HodKInson I.D. 2004. Plant recruitment in the High Arctic: Seed bank and seedling emergence on Svalbard. Journal of Vegetation Science 15: 115-224.

EdwardS J.A. 1974. Studies in Colobanthus quitensis (Kunth) Bartl. and Deschampsia antarctica Desv.: VI. Reproductive performance on Signy Island. British Antarctic Survey Bulletin 39: 67-86.

FAWZI N.M., FAWZI A.M. and Mohamed A.A.-H.A. 2010. Seed morphological studies on some species of Silene L. (Caryophyllaceae). International Journal of Botany 6: 287-292.

GieŁwanowska I., BocheneK A., GojŁo E., GóRecki R., Kellmann W., PastorczyK M. and SZCZUKA E. 2011. Biology of generative reproduction of Colobanthus quitensis (Kunth) Bartl. from King George Island, South Shetland Islands. Polish Polar Research 32: 139-155.

GieŁWANOWSKa I., BOCHENEK A. and LORO P.M. 2005. Biology of generative reproduction of Deschampsia antarctica. In: L. Frey (ed.) Biology of Grasses. Polish Academy of Sciences, Kraków: 181-195.

GIEŁWANOWSKA I. and KELLMANN-SOPYŁA W. 2015. Generative reproduction of Antarctic grasses, the native species Deschampsia antarctica Desv. and the alien species Poa annua L. Polish Polar Research 36: 261-279.

GieŁwanowska I., PastorczyK M., Kellmann-SopyŁa W., GórniaK D. and GóRecki R.J. 2015. Morphological and ultrastructural changes of organelles in leaf mesophyll cells of the Arctic and Antarctic plants of Poaceae family under the cold influence. Arctic, Antarctic and Alpine Research 47: 17-25.

GieŁWANOWSKa I., PASTORCZYK M., LisowsKa M., WęGRZYN M. and GÓReCKI R.J. 2014. Cold stress reflects on ultrastructure organelles in polar Caryophyllaceae. Polish Polar Research 35: $627-646$. 
HENNION F. and WALTON D.W.H. 1997. Ecology and seed morphology of endemic species from Kerguelen Phytogeographic Zone. Polar Biology 18: 229-235.

Holtom A. and GREENE S.W. 1967. The growth and reproduction of Antarctic flowering plants. Philosophical Transactions of the Royal Society of London, Series B, Biological Sciences 252: 323-337.

Hörandl E., Dobeš Ch., Suda J., Vít P., URfus T., Temsch E.M., Cosendai A.C., Wagner J. and LADINIG U. 2011. Apomixis is not prevalent in subnival to nival plants of the European Alps. Annals of Botany 108: 381-390.

JÓNSDÓTTIR I.S. 2005. Terrestrial ecosystems on Svalbard: Heterogeneity, complexity and fragility from an Arctic island perspective. Biology and Environment: Proceedings of the Royal Irish Academy 105: 155-165.

KELlY E.Z., TUNC-OZDEMIR M. and HARPER J.F. 2010. Temperature stress and plant sexual reproduction: uncovering the weakest links. Journal of Experimental Botany 61: 1959-1968.

Kellmann-SopyŁa W. and GieŁWANOWSKA I. 2015. Germination capacity of five polar Caryophyllaceae and Poaceae species under different temperature conditions. Polar Biology 38: 1753-1765.

Kerlick M.J., Macmahon J.A., PARMENTER R.R. and SisSON D.V. 1986. Native seed preferences of shrub-steppe rodents, birds and ants: the relationships of seed attributes and seed use. Oecologia 67: 327-337.

KlimeŠOvá J., DoležAl J., Prach K. and KoŠnar J. 2012. Clonal growth forms in Arctic plants and their habitat preferences: a study from Petuniabukta, Spitsbergen. Polish Polar Research 33: $421-442$.

KoltunOW A.M. 1993. Apomixis: Embryo sac and embryos formed without meiosis or fertilization in ovules. Plant Cell 5: 1425-1437.

LECK M.A., PARKER V.T. and SimPSON R.L. 1989. Ecology of soil seed banks. Academic Press, San Diego, California: 283-305.

LEVKovsKy V.P., TIKHMENEV E.A. and LEVKOVSKY E.P. 1981. Cleistogamy in Arctic grasses. Botanicheskij Zhurnal 66: 116-120.

LEWIS SMITH R.I. 1984. Terrestrial plant biology of the Sub-Antarctic and Antarctic. In: R.M. Laws (ed.) Antarctic Ecology. Academic Press, London: 61-162.

LINSKENS H.F. 1988. Present status and future prospects of sexual reproduction research in higher plants. In: M. Cresti, P. Gori and E. Pacini (eds) Sexual reproduction in higher plants. Springer, Berlin: 451-457.

MasCARENHAS J.P. 1989. The male gametophyte of flowering plants. The Plant Cell 1: 657-664.

MCGRAW J.B. and DAY T.A. 1997. Size and characteristics of a natural seed bank in Antarctica. Arctic, Antarctic and Alpine Research 29: 213-216.

MCGRAW J.B. and VAVREK M.C. 1989. The role of buried viable seeds in arctic and alpine plant communities. In: M.A. Leck, V.T. Parker and R.L. Simpson (eds) Ecology of soil seed banks. Academic Press, New York: 462 pp.

MOLAU U. 1993. Relationships between flowering phenology and life history strategies in tundra plants. Arctic, Antarctic and Alpine Research 25: 391-402.

MÜLler E., COOPER E.J. and Alsos I.G. 2011. Germinability of arctic plants is high in perceived optimal conditions but low in the field. Botany 89: 337-348.

NishiYAmA I. 1984. Climatic influence on pollen formation and fertilization. In: S. Tsunoda, N. Takahashi (eds) Biology of Rice, Elsevier, Amsterdam: 153-171.

PARNIKOZA I., KOZERETSKA I. and KUNAKH V. 2011. Vascular plants of the Maritime Antarctic: origin and adaptation. American Journal of Plant Sciences 2: 381-395. 
PhilipP M., BÖCheR J., MATTSON O. and WoOdell S.R.J. 1990. A quantitative approach to the sexual reproductive biology and population structure in some arctic flowering plants Dryas integrifolia, Silene auacalis, Ranunculus nivalis. Meddeletser on Grønland. Bioscience, Commission for Scientific Research in Greenland, Copenhagen 34: 60 pp.

PIROŻNIKOW E. 1993. Populations of Saxifraga oppositifolia L. in Spitsbergen tundra in different ecological conditions. Polish Polar Research 14: 355-382.

Prestrud P., Strøm H. and Goldman H.V. 2004. A catalogue of the terrestrial and marine animals of Svalbard. Skrifter 201. Norwegian Polar Institute, Troms $\varnothing: 142$ pp.

RUHLAND C.T. and DAY T.A. 2001. Size and longevity of seed banks in Antarctica and the influence of ultraviolet-B radiation on survivorship, growth and pigment concentrations of Colobanthus quitensis seedlings. Environmental and Experimental Botany 45: 143-154.

SRINIVASAN A., SAXENA N.P. and JOHANSEN C. 1999. Cold tolerance during early reproductive growth of chickpea (Cicer arietinum L.): genetic variation in gamete development and function. Field Crops Research 60: 209-222.

TILMAN D. 1988. Plant strategies and dynamic and structure of plant communities, Princeton University Press, Princeton: 376 pp.

Walton D.W.H. 1982. Floral phenology in the South Georgian vascular flora. British Antarctic Survey Bulletin 55: 11-25.

WódKIEwicz M., Galera H., ChwedorzewsKa K.J., GiełwanowsKa I. and Olech M. 2013. Diaspores of the introduced species Poа аппиа L. in soil samples from King George Island (South Shetlands, Antarctica). Arctic, Antarctic and Alpine Research 45: 1-5.

Received 24 June 2016

Accepted 10 November 2016 